\title{
Reasoning Abilities and Learning Math: A Möbius Strip?
}

\author{
Luciana Pereira Brito ${ }^{1 *}$, Leandro Silva Almeida ${ }^{1,2}$, António José Meneses Osório ${ }^{1,2}$ \\ ${ }^{1}$ Research Centre on Education (CIEd), PORTUGAL \\ ${ }^{2}$ University of Minho, PORTUGAL \\ *CORRESPONDENCE: $\$ lucianapbrito@gmail.com
}

\begin{abstract}
Long have we known that reasoning abilities are linked to learning, and specifically to learning mathematics. Even intelligence, considered a controversial construct, plays a significant role in the research on the explanation of academic performance. This article intends to highlight some important cognitive abilities or dimensions relevant to learning mathematics, synthesizing some research that defines such constructs and relates them to mathematical learning and achievement. General considerations about designing and implementing meaningful learning experiences are presented.
\end{abstract}

Keywords: reasoning abilities, learning, mathematical reasoning

\section{INTRODUCTION}

Throughout life individuals interact and perform in a variety of contexts and for a variety of purposes, and such interactions and performances are framed by and depend upon a multitude of social and psychological conditions that characterize, drive and transform those same individuals. When talking about children and adolescents and those interactions and performances take place at school, the social, psychological and cognitive developments entangles with the curricula. Then, from learning experiences, knowledge is to be acquired and skills are to be developed, hoping to guide and prepare students to appreciate and function fruitfully in the world, thinking critically and overcoming challenges (Asia \& OECD, 2018; Gomes et al., 2017; OECD, 2014; UNESCO, 2016). In fact, fostering the development of thinking skills has long been considered one of the most important educational goals (Almeida \& Araújo, 2014; Molnár, Greiff, \& Csapó, 2013; Ponte, Mata-Pereira, \& Henriques, 2012a; Resnick, 1987).

As mathematics likely builds on several cognitive abilities (Szücs, Devine, Soltesz, Nobes, \& Gabriel, 2014; Yen, Jacqueline, Beatrix, \& Cohen, 2016), meaningfully learning mathematics may be one of the most demanding cognitive activity in school. This article presents a brief review of intelligence in the psychometric approach and learning related processes and activities. Traditional connections between specific cognitive abilities and learning mathematics are presented, articulating the concept of mathematical reasoning within mathematics education community. Final remarks present considerations about teacher's education and the importance of keeping close attention to personal variables of students when researching about learning and when designing and implementing learning experiences.

Article History: Received 31 July $2019 \bullet$ Revised 26 October $2019 \bullet$ Accepted 26 October 2019

(C) 2020 by the authors; licensee Modestum Ltd., UK. Open Access terms of the Creative Commons Attribution 4.0 International License (http://creativecommons.org/licenses/by/4.0/) apply. The license permits unrestricted use, distribution, and reproduction in any medium, on the condition that users give exact credit to the original author(s) and the source, provide a link to the Creative Commons license, and indicate if they made any changes. 


\section{THE ACTION TO LEARN: RELATED VARIABLES, PROCESSES AND COGNITIVE ABILITIES}

Säljö (1979) interviewed 90 individuals from 15 to 73 years old and with 6 to 16/17 uninterrupted years of schooling to find their conceptions of learning. From one perspective, embraced by the majority of the participants, it was seen as accumulating knowledge or "discrete units of information" (Säljö, 1979, p. 446): therefore, a very good learner was perceived as one that accumulates a significant quantity of knowledge in a short period of time. The other group problematized learning, and by doing so different aspects emerged: learning seemed to depend on contexts and its implicit rules. A subgroup focused on the concept of real learning as understanding, which was described as involving perspectives and interpretations, in a process aimed to clarify the general meaning of what is really to be learned.

While understanding learning as memorizing has its roots in behaviorism (Murtonen, Gruber, \& Lehtinen, 2017), where reinforcement and repetition are used to shape learner's behavior, the notion of learning as understanding is connected to what David Ausubel postulated in his theory of meaningful learning (Ausubel, Novak, \& Hanesian, 1980). In Ausubel's theory, anchored in the cognitive and constructivist paradigm, meaningful learning - perhaps one of the most common concepts in the learning literature - is defined as a process through which new information relates non-arbitrarily and substantively to elements of the individual's cognitive structure. Non-arbitrariness refers to the interaction of the new information with a specific material of the cognitive structure, while the substantive characteristic indicates that the new information is not stored literally, but rather in a quality that allows the individual to enunciate it by his own words and apply it to new situations (Ausubel et al., 1980). According to Ausubel et al. (1980) there are two different phases of the learning process, in which two different dimensions are visible: in the first phase the new information becomes available to the student in an environment that fosters learning by reception and/or by discovery. Subsequently, it will be the learner's action to dictate the type of learning that may occur: it will be mechanical if his action is the attempt to merely memorize it, arbitrarily; will be, at the other extreme, meaningful, if he tries to retain the new information by relating it to what he already knows.

Parallel and complementary concepts also emerged in the 70's and 80's specifically regarding students approaches to learning in higher education, classified as surface and deep learning (Marton \& Säljö, 1976). In the surface approach to learning, students intentions are to memorize bits of information, and they prefer teachers who provide pre-digested information ready to be learned (Entwistle, 1991). The student who engages in a deep approach intents to understand contents, themes and ideas, preferring to be stimulated and challenged. A utilitarian vision of the assessment score as being the major goal for learning is found mostly on students with a surface approach (Entwistle \& Ramsden, 1982). Focusing on the complexities of the learning outcomes, Biggs and Collis (1982) proposed a model parallel to Bloom's Taxonomy: the SOLO (Structure of the Observed Learning Outcome) Taxonomy, which indicates different levels of understanding that can be achieved when engaging in learning. According to Biggs and Collis (1982), learning starts with picking up one or few aspects of the task (uni-structural level), and the learning outcome is to identify, name or follow simple procedures; then the learner can pick several aspects but still unrelated (multi-structural level), and the outcome is to compare, combine, describe, list and perform serial skills. Learning how to integrate those several aspects into a whole sets up the relational level, where the outcome is to be able to explain, relate and analyze. Finally, and desirably, generalizing that same whole to a yet untaught application is the extended abstract level, where the learner can also hypothesize and reflect.

The components of any action to learn and the predisposition to engage in it are conditioned by intrapersonal variables: cognitive structure, cognitive abilities, and personality and motivational factors (Ausubel et al., 1980). In general, one can assume that the occurrence of any learning depends on the successful use of mental abilities to encode, store and retrieve information to and from memory (Almeida, 2002). The concept of self-regulated learner proposed by Zimmerman (1990) points to a student actively participating in his own learning process by mobilizing his metacognitive, behavior and motivational capabilities (Ganda \& Boruchovitch, 2018). In the first of the three phases of Zimmerman's model, which occurs prior to learning, the self-regulated student is influenced by his own motivations and plans the action to be taken, assessing the technical aspects of the activity like materials, resources and time. The second phase - the implementation of that same plan - involves variables like attention, concentration and solving parallel problems that interfere with the process of learning. In the third and last phase the student assesses the overall results and performs self-judgments, adaptively or defensively reacting to his strategies' successes (Ganda \& Boruchovitch, 2018). 
In this sense metacognition is also a learning process (Shute, 1992), where one thinks about his learning and limitations (Alzahrani, 2017; Flavell, 1979; Shute, 1992).

Focusing on the material to be learned and the subjacent intellectual activity, Shute (1992) proposed that metacognition is aimed to control other learning processes, named associative learning, procedural learning and inductive reasoning. Associative learning is "the ability to remember and voluntarily recall specific associations between stimuli” (Kaufman, DeYoung, Gray, Brown, \& Mackintosh, 2009, pp. 374-375), entailing the mechanism by which the individual connects mental representations of observed phenomena (Mitchell, De Houwer, \& Lovibond, 2009). As it underlies higher-order cognitive processes like forming concepts (Mondragón, Alonso, \& Kokkola, 2017), associative learning is linked to general intelligence (Kaufman et al., 2009). Classical studies of simple forms of associative learning can be found in Pavlov's and Thorndike's work (Delamater \& Lattal, 2014). Procedural learning refers to the compiling, grounded in practice, of procedures or rules into efficient skills (Knowlton, L.M. Siegel, \& D. Moody, 2017), and is often associated with rote learning (Fauskanger \& Bjuland, 2018). Inductive reasoning, unlike the other learning processes, constitutes itself a cognitive ability to infer rules and generalize from analogies, examples or, "transcending information" (Shute, 1992, p. 20), from simple observation, therefore influencing the success of knowledge acquisition and application (Molnár et al., 2013). Being reasonable to say that the intensity, quality and success of the activation of these processes may constitute factors affecting the quality of any learning, different learning materials most surely require different proportions of those same processes: to acquire vocabulary one recalls associative learning (Zakeri \& Khatibi, 2014); to develop mastery in using an algorithm one recalls procedural learning (Knowlton et al., 2017). Inductive reasoning is required to come up with a mathematical formula that resumes a phenomena (Haverty, Koedinger, Klahr, \& Alibali, 2000), and metacognition allows one to evaluate the suitability of a chosen strategy (Flavell, 1979) and/or the plausibility of an obtained solution of a problem.

Mathematics is an important component of the school curricula (Inglis \& Simpson, 2009): it encompasses a vast and diverse body of knowledge and skills that not only model and support other sciences but are also themselves in the core of specific cognitive abilities that, together with others, define what we commonly call intelligence. Some of the early definitions of intelligence make a close connection to learning, describing it as the ability to learn (Binet \& Simon, 1916, cited by Kaufman et al., 2009; Sternberg, 1983). In fact, intelligence has traditionally been associated with learning in both directions: intelligence seem to facilitate learning (Primi, Ferrão, \& Almeida, 2010), and learning seem to develop intelligence (Wang, Ren, \& Schweizer, 2017).

\section{Cognitive Abilities, Learning, Mathematical Learning and Achievement}

Intelligence is not an easy construct to define (Legg \& Hutter, 2007; Neisser et al., 1996), but efforts have been made throughout the years to make it easier to understand and assess. The most widely used approach to intelligence is the psychometric (Neisser et al., 1996): generally speaking, it relies on finding strong correlations between performances in two or more different tasks (Embretson \& McCollam, 2000; Sternberg, 1983), each one supposedly requesting different cognitive abilities understood within the theory as manifestations of intelligence, from which emerges a latent variable that seems to explain the phenomena in a broader picture (Sternberg, 1983).

The Cattel-Horn-Carrol (CHC) model of cognitive abilities is, according to McGrew (2009), the consensual model used in the psychometric approach to understand the structure of human intelligence. It emerged from the integration of Carrol's three strata model - the result of an extensive exploratory factor analysis - with the Cattel-Horn model of fluid and crystallized intelligences (McGrew, 2009). It is defined by the existence of three strata: stratum III, more general, constitutes the general factor of intelligence g; the stratum II is composed of 10 broad factors, which also decompose into specific, narrow factors that are located in stratum I (Almeida, Guisande, \& Ferreira, 2009). These narrow factors or abilities are the ones observable and therefore usually measurable in intelligence tests (McGrew, 2009). Table 1 presents a simplification of broad abilities of the stratum II and, for each one of them, some of their narrow abilities in stratum I.

Quantitative knowledge consists of acquired knowledge of mathematical symbols, operations, procedures and other related skills such as using the calculator, and can be defined as "the depth and breadth of declarative and procedural knowledge related to mathematics" (Flanagan \& Harrison, 2018, p. 123), "but not reasoning with this knowledge" (McGrew, 2009, p. 6). According to Flanagan and Harrison (2018), while Mathematical Knowledge involves the ability to answer questions like "What is $\pi$ ?" or "What is the Pythagorean Theorem?", Mathematics Achievement calls for the ability to perform calculations, and is usually measured with two different types of items defined by the presence (or not) of a context or scenario. But beneath the obvious contribution of mathematical thinking to the corpus of abilities that integrates the general 
Table 1. Simplification of broad abilities of the stratum II and some abilites of the stratum I of the CHC Model of Cognitive Abilities (McGrew, 2009)

\begin{tabular}{ll}
\hline stratum II (broad abilities) & stratum I (narrow abilities) \\
\hline Fluid reasoning (Gf) & General sequential (deductive) reasoning (RG); Induction (I); ... \\
\hline Comprehension-knowledge (Gc) & Language development (LD); Communication ability (CM); ... \\
\hline Short-term memory (Gsm) & Memory span (MS); Working Memory (MW) \\
\hline Visual processing (Gv) & Visualization (VZ); Imagery (IM); ... \\
\hline Auditory processing (Ga) & Phonetic coding (PC); ... \\
\hline Long-term storage and retrieval (Glr) & Associative memory (MA); Word fluency (FW); ... \\
\hline Processing speed (Gs) & Perceptual speed (P); Speed of reasoning (RE); ... \\
\hline Reaction and decision Speed (Gt) & Simple reaction time (R1); Mental comparison speed (R7); ... \\
\hline Reading and writing (Grw) & Reading decoding (RD); Writing ability (WA); ... \\
\hline Quantitative knowledge (Gq) & Mathematical knowledge (KM); Mathematics achievement (A3) \\
\hline
\end{tabular}

factor intelligence, there are other narrow factors intimately connected to mathematics that include the abilities ultimately required to think and perform within mathematics, namely Working Memory (Chung Yen, Jacqueline, Beatrix, \& Roi Cohen, 2016; Corso \& Dorneles, 2012; Floyd, Evans, \& McGrew, 2003; Fung \& Swanson, 2017; Geary, 2011), Fluid Reasoning (Cormier, Bulut, McGrew, \& Singh, 2017; Floyd et al., 2003; Green, Bunge, Chiongbian, Barrow, \& Ferrer, 2017; Stelzer, Andrés, Canet Juric, Urquijo, \& Marta Richards, 2019) and Visualization (Joly, Muner, Silva, \& Prieto, 2011; Lubinski, 2010; Mulligan, 2015).

When mentally adding a shopping bill, one has to maintain parcels available in memory while summing them, and in order to do it uses its working memory (MW). This ability, theoretically developed and differing in nature from the other narrow factors (McGrew, 2009), refers to "the system or systems that are assumed to be necessary in order to keep things in mind while performing complex tasks such as reasoning, comprehension and learning" (Baddeley, 2010, p. 136). The very definition of working memory proposed by Baddeley (2010) points to its relevance to learning in general, and theoretical and empirical evidence indicate the same (Wang et al., 2017). Working memory has a strong association with word problem solving (Fung \& Swanson, 2017) and knowledge of fractions (Hansen et al., 2015; Stelzer et al., 2019). Manifestations of problems with working memory include using primitive counting strategies and not doing mental calculations, not remembering the result of recently performed operations (Corso \& Dorneles, 2012) and not remembering the sequence of steps of an operation (Corso \& Dorneles, 2012; Fung \& Swanson, 2017), making difficult to learn and perform within math (Corso \& Dorneles, 2012).

Also in the stratum II of the CHC model is Visual Processing (factor Gv), which refers to the ability to solve problems by using simulated mental images, often in conjunction with perceived images (Schneider \& McGrew, 2012). Defined by Loman (1996, as cited by Almeida et al., 2009) as spatial fitness, it involves the ability to generate, perceive, retain, analyze, manipulate and transform visual images (Almeida et al., 2009). The narrow nuclear factor of Gv is Visualization (VZ): the ability to understand complex objects and patterns and to mentally simulate how they will be presented if transformed, like rotated, altered in size or partially hidden (Schneider \& McGrew, 2012). In this narrow ability one can specifically identify spatial visualization, defined as the ability to mentally manipulate complex three-dimensional figures (Prieto \& Velasco, 2008) and has traditionally been assessed through different types of items, often requesting the identification of a figure resulting from transformation (rotation, reflection or both) of a three-dimensional figure, or the identification of sections of solids, or even the association of solids to their nets (Yildiz \& Özdemir, 2017).

In psychology research and in general, performance in mathematics maintains an insignificant relationship with the broad ability of Visual Processing (Cormier et al., 2017; Floyd et al., 2003; McGrew \& Evans, 2004; McGrew \& Wendling, 2010). In fact, as McGrew and Evans (2004) report, visual processing skills have been "cursed with a schizophrenic relationship with intelligence researchers" (p.14), and there is no consistency in predicting academic success or job. Although researchers believe this ability may contribute to the early stages of mathematical skills' development in the early years, Floyd et al. (2003) argue that the comparison of this ability with mathematics performance could be conditioned by the mathematical content of the items in the instrument used to assess it, suggesting the need to conduct other studies to substantiate the importance of Visual Processing in predicting certain mathematical skills. Nevertheless, there is a large number of studies that seem to suggest otherwise, especially the ones focused on spatial visualization (Bishop, 2008; Joly et al., 2011; Lubinski, 2010; Mulligan, 2015). In fact, within mathematics' education research community it is consensual that the narrow ability of Visualization is relevant to all areas of Mathematics and particularly to Geometry (Sinclair et al., 2016; Yildiz \& Özdemir, 2017), being itself an object of prolific 
research often under the names of visuospatial reasoning, visualizing, spatial reasoning, spatial thinking and visual reasoning (Sinclair et al., 2016). Spatial skills are associated with success in science, technology, engineering, and mathematics domains (Gilligan, Flouri, \& Farran, 2017; Julià \& Antolì, 2017; Kell \& Lubinski, 2013). Even tough, as formulated by Bishop (2008), spatial abilities may constitute "an area like language, which is every teacher's responsibility” (p.79), Geometry Education's field produces fertile ground to, in natural contexts, see and learn about spatial reasoning in curricular motion (Sinclair et al., 2016), for it plays an important role in the process of interpreting visual information related to learning geometry (Kösa, 2016). In a study of quasi-experimental design with future teachers of Mathematics, Kösa (2016) submitted the experimental group to 10 weeks of classes on Geometry Spatial Analysis with Geogebra software. At the end of the experiment, the experimental group obtained, higher scores on items of the spatial reasoning test involving solids rotations and cube sections. Also previous knowledge and spatial reasoning explained about $84 \%$ of students' success in Spatial Analytical Geometry achievement. This interconnection between spatial reasoning and learning math is more obvious when simply observing that the ability is primarily required to understand and interpret the two-dimensional views of three dimensional objects found in math textbooks (Kösa, 2016), from which one can comprehend the urgency of an intentional strategy to develop spatial reasoning in spatial geometry pedagogical activities.

As pointed earlier, induction involves analyzing observations of similar products and inferring a rule that explains all observations. Mathematics itself is referred by innumerous authors as the science of patterns (Devlin, 2002; M. Resnick, 1997; Schoenfeld, 1992; Vale, 2013). Since generalization is universally understood to be an essential mathematical activity students must engage on (NCTM, 2000), the process of finding regularities or patterns in numbers/figures' traits or in numerical/geometrical sequences' behaviors is often discussed within mathematics' education. But it's not just inductive reasoning that is in the essence of mathematical thinking: deductive reasoning, through which conclusions are drawn upon known premises, is in the genesis of mathematical propositions' formation. Formal mathematical proofs rely on deductive reasoning (Laamena, Nusantara, Irawan, \& Muksar, 2018), and simple forms of it can be found as early as in kindergarten children using the type of syllogism Modus Ponens (Schwartz, Epinat-Duclos, Léone, \& Prado, 2017). According to Schwartz et al. (2017), rejecting the propositional fallacy affirmation of the consequent is often considered a hallmark of the emergence of deductive reasoning in children. Connecting an experimental study with 6 years-old children with a 16 months longitudinal study with working memory as a control variable, Nunes et al. (2007) established a long theorized causal link between logical (or deductive) reasoning and mathematical learning.

One simple exercise requiring induction that can be seen in most (if not all) math books and intelligence tests is recognizing the formation law of a numeric or geometric sequence, to later deduct the identity of a missing term. By observing what happens from one instance to the next, one can find an operation or transformation that is perceived as the law by which all subsequent instances will be created; therefore, the missing term is found by applying deductive reasoning. Such exercise calls for one's analogical reasoning, which involves recognizing relationships or shared attributes of conceptual or perceptual experiences (Buehl \& Alexander, 2004). As noted by Stevenson, Bergwerff, Heiser, and Resing (2014, p. 52), "much of learning in school is considered to be a form or analogical reasoning, in which knowledge about a familiar situation or object is used to learn about a new similar one". Specifically regarding math proficiency, Richland and Hansen (2013) underline the importance of the connected thinking that characterizes analogical reasoning, which involves drawing connections between concepts, problems or representations, as this process conducts to the broad mathematics educational goal of making connections among mathematic ideas (NCTM, 2000). In a study with children from kindergarten, first grade and second grade, Stevenson et al. (2014) concluded that both working memory and analogical reasoning were positively related to mathematics and reading achievement.

In the CHC model induction and deduction are narrow abilities of fluid reasoning. Cattell (1987, cited by Green et al., 2017), conceptualizes fluid reasoning as a scaffold for learning: it refers to mental operations of reasoning in new situations, whose resolution does not depend on acquired knowledge. In general, fluid reasoning explains between $25 \%$ and $40 \%$ of the variance in academic performance (Almeida, Miranda, Salgado, Silva, \& Martins, 2012), but as the age of students increases this percentage decreases (Almeida et al., 2012), which indicates a more active role of other variables such as interests, motivations, academic learning and everyday experiences (Lemos, Casanova, \& Almeida, 2015). The connection between school performance and the respective areas of reasoning is emphasized: for example, secondary school science students have better results in items involving numerical and spatial reasoning (Almeida \& Lemos, 2006). Several studies point to a significant relation between fluid reasoning and: math calculation skills (Cormier 
et al., 2017; Floyd et al., 2003); math reasoning and problem solving (Cormier et al., 2017; Floyd et al., 2003; Haverty et al., 2000), fraction knowledge (Stelzer et al., 2019) and mathematics achievement (Cormier et al., 2017; Floyd et al., 2003; Green et al., 2017) throughout childhood and adolescence. Primi et al. (2010) found out that, over a two-year period, important inter-individual differences take place in intra-individual growth patterns in math achievement, with some subjects increasing their math scores at a faster rate than others. One substantial finding of these authors was that "those individual differences in growth rate could be explained, at least in part, by fluid intelligence. Individuals with higher fluid intelligence reveal a faster increase in math scores over a span of two years than do individuals with a lower fluid intelligence" (Primi et al., 2010, p. 450).

Since the hallmark indicators of Gf are generally considered to be inductive and deductive reasoning (McGrew, 2009), mental operations regarding fluid reasoning often include, drawing inferences, concept formation, classification, generating and testing hypothesis, identifying relations, comprehending implications, problem solving, extrapolating, and transforming information (McGrew, 2009). All of these processes are related to what is defined in Mathematics Education by mathematical reasoning. The term reasoning is very common in mathematics education domain, with a diffuse meaning and frequently used as equivalent to thinking (Mata-Pereira \& Ponte, 2017). Mathematical reasoning is defined by NCTM (2009) as the process of manipulating and analyzing objects, representations, diagrams, symbols, or statements to draw conclusions based on evidence or assumptions. It is "an evolving process of developing and evaluating arguments through conjecturing, generalizing, and investigating why” (Lannin, Ellis, Elliot, \& Zbiek, 2011). According to English (2013), analogies, metaphors and images are vehicles of mathematical reasoning, as it entails "reasoning with structures that emerge from our bodily experiences as we interact with our environment" (p. 1985); it requires imagination to transform the products of those same experiences into models of abstract thought. Mathematical reasoning means making justified inferences (Pólya, 1990) using deductive, inductive and abductive processes (Mata-Pereira \& Ponte, 2017). Primary components of mathematical reasoning processes are conjecturing (Lannin et al., 2011), generalizing and justifying (Lannin et al., 2011; Mata-Pereira \& Ponte, 2017). Even though VZ entails a type of reasoning requiring mental manipulation of images that unequivocally relates to understanding and performing successfully within geometry (Clements \& Battista, 1992), it does not seem to be seen as a component of mathematical reasoning like induction or deduction but more like an ability that assists them within geometrical contexts.

\section{FINAL REMARKS}

Together with sense-making - which involves "developing an understanding of a situation, context or concept, by connecting it with other knowledge" (NCTM, 2009), mathematical reasoning should occur in every mathematics classroom (Martin, 2009; Mata-Pereira \& Ponte, 2017). Nevertheless, studies seem to present a different reality. In an exploratory study to identify factors that influence learning of mathematical concepts by engineering students, Alves, Coutinho, Rocha, \& Rodrigues (2016) performed focus groups interviews with 38 students, from which interpretation and reasoning emerged as the major difficulties in learning mathematical concepts. According to a participant, "mathematic becomes demanding when it ceases to be just calculation and begins to involve reasoning, since it ceases to be methodical and mechanical to be more abstract and ambiguous. (...) In high school we are used to doing similar exercises, and everything that goes beyond this... for most students it becomes difficult to solve problems." The Möbius strip can function as a metaphor for different relations between intelligence, learning and mathematics. The most obvious relation is that mathematical reasoning relies on fluid reasoning; therefore, engaging in the first implies activating cognitive abilities highly correlated to a general factor of intelligence. Another relation, now between learning and cognitive abilities, entails two different directions: cognitive abilities facilitate learning, but can learning improve cognitive abilities? Is there a feeding loop?

By reviewing literature about the complexities involved in the action to learn and cognitive abilities directly and indirectly related to mathematics performance and learning, this article intended to provide a broader picture about eventual origins of students' difficulties, both in mathematical reasoning and in learning mathematical concepts and procedures. In particular, understanding the connection between intelligence and learning can help to explain different learning outcomes and to guide teachers' efforts to effectively promote meaningful learning experiences. The other direction of this connection - that is to say learning develops cognition - is to be address with caution, as judgments of causality in educational research are often made, according to Nisbett (2009), with questionable methods to obtain, produce or assess the evidence observed. This endeavor - from-learning-to-cognition - can be safely addressed in a "twist" on the strip: schools should 
provide learners with learning experiences that give them opportunities to reach their intelligence potential (Nisbett, 2016), and teachers should frequently request students to use their reasoning abilities, stimulating their activation (Ponte, Mata-Pereira, \& Henriques, 2012b). For instance, and focusing specifically on spatial abilities, Clements (1999) suggests that, in order to stimulate spatial reasoning, teachers must prepare materials and design activities to engage students in spatial reasoning, requesting them to locate, draw, transform and mentally manipulate images. To effectively address the problem of explicitly stimulate students' cognitive development, educational and professional organizations co-responsible to guide curricular conception and implementation - such as the National Council of Teachers of Mathematics - produce regularly principles and norms containing recommendations for teachers. To add to what has already been listed such documents require a holistic vision of the individual that is to get engaged in the learning experience and the learning experience itself (Almeida \& Araújo, 2014), remembering Ausubel et al. (1980) intrapersonal conditions connected to the action to learn and to the predisposition to engage in it. Namely: teachers should engage students in activities that stimulates their intrinsic motivation and ask them to persevere and to control their impulsivity (Nisbett et al., 2012), to think with flexibility, to think about what they know and don't know, to supervise their work comparing to others' work, to question problems and solutions, to organize/structure knowledge and to transfer knowledge to other situations (Almeida \& Araújo, 2014).

In fact, in the last years efforts have been made by educational government entities throughout the world (Asia \& OECD, 2018; UNESCO, 2016) to develop curricular and pedagogical settings that foster the development of reasoning abilities and critical thinking, while actively engaging students in learning. But, as teaching and learning processes are often assumed to implicitly foster higher order thinking skills (de Koning, Hamers, Sijtsma, \& Vermeer, 2002; Molnár et al., 2013), teachers do not explicitly pursue the stimulation of thinking skills such as inductive reasoning or problem solving (de Koning et al., 2002; Molnár et al., 2013). Addressing this complex and open problem requires an analysis of different components involved, which must be carefully articulated and thoroughly assessed.

According to de Koning et al. (2002), research has shown that there are ways to significantly and effectively develop thinking skills, for instance by enriching school materials and modifying teaching methods. Liu and Huang (2015) highlight the value of digital simulation in education by allowing students to actively explore, examine, and extend their knowledge, engaging in meaningful learning. According to these authors, by providing students with the possibility to manipulate the parameters of a system and thus the active control of the simulation process, the use of simulators allows them to better understand the complex and abstract concepts involved, supporting the development of a deeper knowledge and a more reflexive thinking. Specifically in mathematics, digital simulators provide opportunities for pattern-noticing and sense-making (Findley, Whitacre, \& Hensberry, 2017). Having thus the potential to stimulate inductive reasoning, digital simulators can be effective in attaining such goal if explored in pedagogical experiences carefully designed to be meaningful to the student (Findley et al., 2017).

Teachers' initial and life-long education is another serious component that requires a metacognitive analysis, focused on approaches to learning and meaningful learning. Universities and other professional educational institutions and organizations must provide (pre-service) teachers with meaningful learning experiences, focusing in different aspects of design, implementation and assessment. Designing such experiences to teachers requires a meticulous diagnostic about their scientific and pedagogical knowledge, their beliefs about teaching and learning and the integration of digital technology, their personal and professional motivations, and the context in which they teach. If teachers don't relate new information to what they already know but arbitrarily store it, aiming to reproduce it in an evaluative moment, then they will most likely take a surface approach to learning, and chances are that, in a new situation, they won't be able to recognize its usefulness and won't apply it, or will perform poorly. It is reasonable to say that, independent of personal styles of learning, rote teaching will, in some degree, produce rote learning; therefore, a central part of the formative process should be the activation and careful mediation of a dialectic interaction between old and 21st century teachers and students (Scott, 2015), that could be achieved by adopting empowering strategies such as Digital Games Design (Oliveira, Osório, \& Dourado, 2018). As a goal of teachers' initial and life-long education is the development of pedagogical competence, experiences should include collaborative work and action-research applied to solve real classroom problems (Elliott, 2012), with trainers performing supervision of each individual teacher learning process, orienting their efforts, promoting formative assessments and providing them with moments to regulate their own learning.

Researchers and practitioners are faced with different challenges. By taking account of different and complex variables that interfere with learning and specifically with learning math, research can be enriched 
with new approaches and mixed methodologies that can only benefit from the intersection of different schools within the Education domain such as Psychology, Didactics, Educational Technology and Pedagogical Supervision. Evaluating students' motivations and cognitive abilities may contribute to better explain the success of different pedagogical settings, strategies or technologies. To help students overcome the challenges they face, an effective contribution of researchers and practitioners surely requires a deep understanding of the problems we face and a scientific research approach to reason and overcome them.

\section{Disclosure statement}

No potential conflict of interest was reported by the authors.

\section{Notes on contributors}

Luciana Pereira Brito - Research Centre on Education (CIEd), Portugal.

Leandro Silva Almeida - Research Centre on Education (CIEd) and University of Minho, PORTUGAL.

António José Meneses Osório - Research Centre on Education (CIEd) and University of Minho, PORTUGAL.

\section{REFERENCES}

Almeida, L., \& Araújo, A. (2014). Aprendizagem e sucesso escolar: variáveis pessoais dos alunos (ADIPSIEDUC Ed.). Braga: ADIPSIEDUC.

Almeida, L., Guisande, M. A., \& Ferreira, A. I. (2009). Inteligência: Perspetivas teóricas. Coimbra: Almedina.

Almeida, L., \& Lemos, G. (2006). Bateria de Provas de Raciocínio: Versões 5/6, 7/9 e 10/12 (Manual Técnico). In. Braga: Universidade do Minho.

Almeida, L., Miranda, L., Salgado, A., Silva, M., \& Martins, V. (2012). Impacto da capacidade cognitiva e das atribuições causais no rendimento escolar na matemática. Quadrante, 11(1), 55-66.

Alves, M., Coutinho, C., Rocha, A., \& Rodrigues, C. (2016). Fatores que influenciam a aprendizagem de conceitos matemáticos em cursos de engenharia: Um estudo exploratório com estudantes da Universidade do Minho. Revista Portuguesa de Educação, 29(1), 259-293. https://doi.org/10.21814/rpe.5998

Alzahrani, K. S. (2017). Metacognition and its role in mathematics learning: an exploration of the perceptions of a teacher and students in a secondary school. International electronic journal of mathematics education, 12(3), 521-537.

Asia, S., \& OECD. (2018). Teaching for Global Competence in a Rapidly Changing World. https://doi.org/https://doi.org/10.1787/9789264289024-en

Ausubel, D., Novak, J., \& Hanesian, H. (1980). Psicologia educacional (E. Nick, Trans.). Rio de Janeiro: Interamericana.

Baddeley, A. (2010). Working memory. Current Biology, 20(4), R136-R140. https://doi.org/10.1016/j.cub.2009.12.014

Biggs, J. B., \& Collis, K. F. (1982). Evaluating the quality of learning: The SOLO taxonomy (Structure of the Observed Learning Outcome). New York: Academic Press.

Bishop, A. J. (2008). Spatial Abilities and Mathematics Education - A Review. In P. Clarkson \& N. Presmeg (Eds.), Critical Issues in Mathematics Education: Major Contributions of Alan Bishop (pp. 71-81). Boston, MA: Springer US.

Buehl, M. M., \& Alexander, P. A. (2004). Seeing the possibilities: Constructing and validating measures of mathematical and analogical reasoning for young children. In Mathematical and analogical reasoning of young learners (pp. 35-58): Routledge.

Chung Yen, L., Jacqueline, T., Beatrix, K., \& Roi Cohen, K. (2016). The Neuroscience of Mathematical Cognition and LearningIS 136. https://doi.org/https://doi.org/10.1787/5jlwmn3ntbr7-en

Clements, D. H., \& Battista, M. T. (1992). Geometry and spatial reasoning. In Handbook of research on mathematics teaching and learning: A project of the National Council of Teachers of Mathematics. (pp. 420-464). New York, NY, England: Macmillan Publishing Co, Inc. 
Cormier, D. C., Bulut, O., McGrew, K. S., \& Singh, D. (2017). Exploring the Relations between Cattell-HornCarroll (CHC) Cognitive Abilities and Mathematics Achievement. Applied Cognitive Psychology, 31(5), 530-538. https://doi.org/10.1002/acp.3350

Corso, L. V., \& Dorneles, B. V. (2012). Qual o papel que a memória de trabalho exerce na aprendizagem da matemática? Bolema: Boletim de Educação Matemática, 26, 627-648.

de Koning, E., Hamers, J. H. M., Sijtsma, K., \& Vermeer, A. (2002). Teaching Inductive Reasoning in Primary Education. Developmental Review, 22(2), 211-241. https://oi.org/10.1006/drev.2002.0548

Delamater, A. R., \& Lattal, K. M. (2014). The study of associative learning: mapping from psychological to neural levels of analysis. Neurobiology of learning and memory, 108, 1-4. https://doi.org/10.1016/j.nlm.2013.12.006

Devlin, K. (2002). Matemática: a ciência dos padrões. Porto: Porto Editora.

Elliott, J. (2012). Reconstructing teacher education (Vol. 221): Routledge.

Embretson, S. E., \& McCollam, K. M. S. (2000). Psychometric Approaches to Understanding and Measuring Intelligence. In R. J. Sternberg (Ed.), Handbook of Intelligence (pp. 423-444). Cambridge: Cambridge University Press.

English, L. D. (2013). Mathematical reasoning: Analogies, metaphors, and images: Routledge.

Entwistle, N. (1991). Approaches to learning and perceptions of the learning environment. Higher Education, 22(3), 201-204. https://doi.org/10.1007/BF00132287

Entwistle, N., \& Ramsden, P. (1982). Understanding Student Learning (routledge revivals): Routledge.

Fauskanger, J., \& Bjuland, R. (2018). Deep Learning as Constructed in Mathematics Teachers' Written Discourses. 13(3), 149-160. https://doi.org/10.12973/iejme/2705

Findley, K., Whitacre, I., \& Hensberry, K. (2017). Integrating Interactive Simulations into the Mathematics Classroom: Supplementing, Enhancing, or Driving? Paper presented at the 39th annual meeting of the North American Chapter of the International Group for the Psychology of Mathematics Education, Indianapolis. Retrieved from https:/files.eric.ed.gov/fulltext/ED581367.pdf

Flanagan, D., \& Harrison, E. (2018). Contemporary intellectual assessment: Theories, tests, and issues. NY: The Guilford Press.

Flavell, J. H. (1979). Metacognition and cognitive monitoring: A new area of cognitive-developmental inquiry. American Psychologist, 34(10), 906-911. https://doi.org/10.1037/0003-066X.34.10.906

Floyd, R. G., Evans, J. J., \& McGrew, K. S. (2003). Relations between Measures of Cattell-Horn-Carroll (CHC) Cognitive Abilities and Mathematics Achievement across the School-Age Years. Psychology in the Schools, 40(2), 155-171.

Fung, W., \& Swanson, H. L. (2017). Working memory components that predict word problem solving: Is it merely a function of reading, calculation, and fluid intelligence? Memory \& Cognition, 45(5), 804-823. https://doi.org/10.3758/s13421-017-0697-0

Ganda, D. R., \& Boruchovitch, E. (2018). A autorregulação da aprendizagem: principais conceitos e modelos teóricos. Psicologia da Educação. Programa de Estudos Pós-Graduados em Educação: Psicologia da Educação. ISSN 2175-3520(46).

Geary, D. C. (2011). Cognitive predictors of achievement growth in mathematics: a 5-year longitudinal study. Developmental psychology, 47(6), 1539-1552. https://doi.org/10.1037/a0025510

Gilligan, K. A., Flouri, E., \& Farran, E. K. (2017). The contribution of spatial ability to mathematics achievement in middle childhood. Journal of Experimental Child Psychology, 163(Supplement C), 107 125. https://doi.org/10.1016/j.jecp.2017.04.016

Gomes, C., Brocardo, J., Pedroso, J., Carrillo, J., Ucha, L., Encarnação, M., ... Rodrigues, S. (2017). Perfil dos alunos à saída da escolaridade obrigatória. Ministério da Educação/Direção Geral de Educação

Green, C., Bunge, S., Chiongbian, V. B., Barrow, M., \& Ferrer, E. (2017). Fluid reasoning predicts future mathematical performance among children and adolescents. Journal of Experimental Child Psychology, 157, 19. https://doi.org/10.1016/j.jecp.2016.12.005

Hansen, N., Jordan, N. C., Fernandez, E., Siegler, R. S., Fuchs, L., Gersten, R., \& Micklos, D. (2015). General and math-specific predictors of sixth-graders' knowledge of fractions. Cognitive Development, 35, 34-49. https://doi.org/10.1016/j.cogdev.2015.02.001 
Haverty, L. A., Koedinger, K. R., Klahr, D., \& Alibali, M. W. (2000). Solving inductive reasoning problems in mathematics: not-so-trivial pursuit. Cognitive Science, 24(2), 249-298. https://doi.org/10.1016/S03640213(00)00019-7

Inglis, M., \& Simpson, A. (2009). Conditional inference and advanced mathematical study: further evidence. Educational Studies in Mathematics, 72(2), 185-198. https://doi.org/10.1007/s10649-009-9187-z

Joly, M. C. R. A., Muner, L. C., Silva, D. V., \& Prieto, G. (2011). Visualização espacial e desempenho em matemática no ensino médio e profissional. Avaliação Psicológica, 10, 181-191.

Julià, C., \& Antolì, J. Ò. (2017). Enhancing spatial ability and mechanical reasoning through a STEM course. International Journal of Technology and Design Education. https://doi.org/10.1007/s10798-017-9428-X

Kaufman, S. B., DeYoung, C. G., Gray, J. R., Brown, J., \& Mackintosh, N. (2009). Associative learning predicts intelligence above and beyond working memory and processing speed. Intelligence, 37(4), 374-382. https://doi.org/10.1016/j.intell.2009.03.004

Kell, H. J., \& Lubinski, D. (2013). Spatial Ability: A Neglected Talent in Educational and Occupational Settings. 35(4), 219.

Knowlton, B., L.M. Siegel, A., \& D. Moody, T. (2017). Procedural Learning in Humans. In.

Kösa, T. (2016). Effects of Using Dynamic Mathematics Software on Preservice Mathematics Teachers' Spatial Visualization Skills: The Case of Spatial Analytic Geometry. Educational Research and Reviews, 11(7), 449-458.

Laamena, C. M., Nusantara, T., Irawan, E. B., \& Muksar, M. (2018). How do the Undergraduate Students Use an Example in Mathematical Proof Construction: A Study based on Argumentation and Proving Activity. International Electronic Journal of Mathematics Education, 13(3), 185198. https://doi.org/10.12973/iejme/3836

Lannin, J., Ellis, A., Elliot, R., \& Zbiek, R. M. (2011). Developing Essential Understanding of Mathematical Reasoning for Teaching Mathematics in Grades Pre-K-8. Reston: NCTM.

Legg, S., \& Hutter, M. (2007). A Collection of Definitions of Intelligence. In B. Goertzel \& P. Wang (Eds.), Advances in Artificial General Intelligence: Concepts, Architectures and Algorithms (pp. 17-24): IOS Press.

Lemos, G., Casanova, J., \& Almeida, L. (2015). Habilidades cognitivas e interesses vocacionais na adolescência: Promovendo percursos de sucesso. In G. Lemos \& L. Almeida (Eds.), Cognição e aprendizagem: Promoção do sucesso escolar (pp. 35-67).

Lubinski, D. (2010). Spatial ability and STEM: A sleeping giant for talent identification and development. 49(4), 344. https://doi.org/10.1016/j.paid.2010.03.022

Martin, W. (2009). Making Reasoning and Sense Making the Focus for Mathematics Education. In. Reston, VA: NCTM.

Marton, F., \& Säljö, R. (1976). On qualitative differences in learning: I - Outcome and Process. British Journal of Educational Psychology, 46(1), 4-11. https://doi.org/10.1111/j.2044-8279.1976.tb02980.x

Mata-Pereira, J., \& Ponte, J.-P. (2017). Enhancing students' mathematical reasoning in the classroom: teacher actions facilitating generalization and justification. Educational Studies in Mathematics, 96(2), 169186.

McGrew. (2009). CHC theory and the human cognitive abilities project: Standing on the shoulders of the giants of psychometric intelligence research. Intelligence, 37(1 (Editorial)), 1-10.

McGrew, \& Evans. (2004). Internal and External Factorial Extensions to the Cattell-Horn-Carroll (CHC) Theory of Cognitive Abilities: A Review of Factor Analytic Research since Carroll's Seminal 1993 Treatise. Retrieved from http://www.iapsych.com/HCARR2.pdf

McGrew, \& Wendling. (2010). Cattell-Horn-Carroll cognitive-achievement relations: What we have learned from the past 20 years of research. Psychology in the Schools, 47(7), 651-675. https://doi.org/10.1002/pits.20497

Mitchell, C. J., De Houwer, J., \& Lovibond, P. F. (2009). The propositional nature of human associative learning. Behavioral and Brain Sciences, 32(2), 183-198. https://doi.org/10.1017/S0140525X09000855

Molnár, G., Greiff, S., \& Csapó, B. (2013). Inductive reasoning, domain specific and complex problem solving: Relations and development. Thinking Skills and Creativity, 9, 35-45. https://doi.org/10.1016/j.tsc.2013.03.002 
Mondragón, E., Alonso, E., \& Kokkola, N. (2017). Associative Learning Should Go Deep. Trends in Cognitive Sciences, 21(11), 822-825. https://doi.org/10.1016/j.tics.2017.06.001

Mulligan, J. (2015). Looking within and beyond the geometry curriculum: connecting spatial reasoning to mathematics learning. 47(3), 511-517. https://doi.org/10.1007/s11858-015-0696-1

Murtonen, M., Gruber, H., \& Lehtinen, E. (2017). The return of behaviourist epistemology: A review of learning outcomes studies. Educational Research Review, 22, 114-128. https://doi.org/10.1016/j.edurev.2017.08.001

NCTM. (2000). Principles and standards for school mathematics. In (Vol. 1). Reston, VA: National Council of Teachers of Mathematics.

NCTM. (2009). Focus in High School Mathematics: Reasoning and Sense Making. In. Reston, VA: The National Council of Teachers of Mathematics Inc.

Neisser, U., Boodoo, G., Bouchard Jr, T. J., Boykin, A. W., Brody, N., Ceci, S. J., . . Sternberg, R. J. (1996). Intelligence: Knowns and unknowns. American psychologist, 51(2), 77.

Nisbett. (2016). Culture and Intelligence. In: London School of Economics and Political Science.

Nisbett, Aronson, J., Blair, C., Dickens, W., Flynn, J., Halpern, D., \& Turkheimer, E. (2012). Intelligence New Findings and Theoretical Developments (Vol. 67).

Nunes, T., Bryant, P., Evans, D., Bell, D., Gardner, S., Gardner, A., \& Carraher, J. (2007). The contribution of logical reasoning to the learning of mathematics in primary school. British Journal of Developmental Psychology, 25(1), 147-166. https://doi.org/10.1348/026151006X153127

OECD. (2014). PISA 2012 Results: Creative Problem Solving: Students' Skills in Tackling Real-Life Problems. In (PISA ed., Vol. 5): OECD Publishing.

Oliveira, A. B. d., Osório, A. J., \& Dourado, L. G. P. (2018, 2018). Compreender a Biologia através do Design de Jogos Digitais: Programando nova estratégia na formação de professores. Paper presented at the Encontro Internacional "A Voz dos Professores de Ciência e Tecnologia".

Ponte, J. P. d., Mata-Pereira, J., \& Henriques, A. (2012a). O raciocínio matemático nos alunos do ensino básico e do ensino superior. Praxis Educativa, 7, 355-377.

Ponte, J. P. d., Mata-Pereira, J., \& Henriques, A. (2012b). O raciocínio matemático nos alunos do ensino básico e do ensino superior.

Prieto, G., \& Velasco, A. D. (2008). Entrenamiento de la visualización espacial mediante ejercicios informatizados de dibujo técnico. Psicologia escolar e educacional, 309-317.

Primi, R., Ferrão, M. E., \& Almeida, L. S. (2010). Fluid intelligence as a predictor of learning: A longitudinal multilevel approach applied to math. Learning and Individual Differences, 20(5), 446-451. https://doi.org/10.1016/j.lindif.2010.05.001

Pólya, G. (1990). Mathematics and plausible reasoning: Induction and analogy in mathematics (Vol. 1): Princeton University Press.

Resnick. (1987). Education and learning to think. Washington D.C.: National Academy Press.

Resnick, M. (1997). Mathematics as a science of patterns. Oxford: Clarendon Press.

Richland, L. E., \& Hansen, J. (2013). Reducing cognitive load in learning by analogy. International Journal of Psychological Studies, 5(4), 69.

Schneider, W. J., \& McGrew, K. S. (2012). The Cattell-Horn-Carroll model of intelligence. In D. Flanagan \& P. Harrison (Eds.), Contemporary intellectual assessment: Theories, tests, and issues, 3rd ed. (pp. 99144). New York: Guilford Press.

Schoenfeld, A. H. (1992). Learning to think mathematically: Problem solving, metacognition, and sensemaking in mathematics. In D. Grows (Ed.), Handbook for Research on Mathematics Teaching and Learning (pp. 334-370). New York: MacMillan.

Schwartz, F., Epinat-Duclos, J., Léone, J., \& Prado, J. (2017). The neural development of conditional reasoning in children: Different mechanisms for assessing the logical validity and likelihood of conclusions. NeuroImage, 163, 264-275. https://doi.org/10.1016/j.neuroimage.2017.09.029

Scott, C. L. (2015). The Futures of learning 2: what kind of learning for the 21st century? In Education, research and foresight: working papers (UNESCO) (14th november 2015 ed.).

Shute, V. J. (1992). Learning processes and learning outcomes. In T. Husen \& T. N. Postlethwaite (Eds.), International encyclopedia of education (2 ed., pp. 3315-3325). New York: Pergamon. 
Sinclair, N., Bartolini Bussi, M. G., de Villiers, M., Jones, K., Kortenkamp, U., Leung, A., \& Owens, K. (2016). Recent research on geometry education: an ICME-13 survey team report. ZDM, 48(5), 691-719. https://doi.org/10.1007/s11858-016-0796-6

Stelzer, F., Andrés, M. L., Canet Juric, L., Urquijo, S., \& Marta Richards, M. (2019). Influence of DomainGeneral Abilities and Prior Division Competence on Fifth-Graders' Fraction Understanding (Vol. 14).

Sternberg, R. J. (1983). Components of human intelligence. Cognition, 15(1), 1-48. https://doi.org/10.1016/0010-0277(83)90032-X

Stevenson, C. E., Bergwerff, C. E., Heiser, W. J., \& Resing, W. C. M. (2014). Working Memory and Dynamic Measures of Analogical Reasoning as Predictors of Children's Math and Reading Achievement. Infant \& Child Development, 23(1), 51-66. https://doi.org/10.1002/icd.1833

Szücs, D., Devine, A., Soltesz, F., Nobes, A., \& Gabriel, F. (2014). Cognitive components of a mathematical processing network in 9-year-old children. Developmental science, 17(4), 506-524. https://doi.org/10.1111/desc.12144

Säljö, R. (1979). Learning about learning. Higher Education, 8(4), 443-451. https://doi.org/10.1007/BF01680533

UNESCO. (2016). Education 2030: Incheon Declaration and Framework for Action for the implementation of Sustainable Development Goal 4: Ensure inclusive and equitable quality education and promote lifelong learning opportunities for all. Retrieved from https://unesdoc.unesco.org/ark:/48223/pf0000245656

Vale, I. (2013). Patterns in figurative contexts: a way to the generalization in mathematics. Revemat: Revista Eletrônica de Educação Matemática, 8(2), 64-81.

Wang, T., Ren, X., \& Schweizer, K. (2017). Learning and retrieval processes predict fluid intelligence over and above working memory. Intelligence, 61, 29-36. https://doi.org/10.1016/j.intell.2016.12.005

Yen, L., Jacqueline, T., Beatrix, K., \& Cohen, K. (2016). The Neuroscience of Mathematical Cognition and Learning. https://doi.org/https://doi.org/10.1787/5jlwmn3ntbr7-en

Yildiz, S. G., \& Özdemir, A. S. (2017). Development of the Spatial Ability Test for Middle School Students. Acta Didactica Napocensia, 10(4), 41-54.

Zakeri, J., \& Khatibi, M. B. (2014). A Much-needed Boost to EFL Learners' Vocabulary; The Role of Associative Learning. Procedia - Social and Behavioral Sciences, 98, 1983-1990. https://doi.org/10.1016/j.sbspro.2014.03.632

Zimmerman, B. (1990). Self-Regulated Learning and Academic Achievement: An Overview (Vol. 25). 